\title{
Pengaruh Penerapan Prinsip-Prinsip Good Governance dan Promosi Terhadap Penerimaan Wakaf Tunai (Pada Lembaga Pengelola Wakaf Di Indonesia)
}

\author{
Indri Yuliafitri ${ }^{1}$, Arie Indra Rivaldi ${ }^{2}$
}

1,2 Fakultas Ekonomi dan Bisnis Universitas Padjadjaran, Jl. Dipati Ukur No. 35 Bandung, 40132, Jawa Barat, Indonesia

Key words:

Good governance

Promotion

Receiving cash waqf fund

\begin{abstract}
A B S T R A C T
Cash waqf is waqf by using cash or money and then the waqf certificate was issued by Islamic financial institutions. The purpose of this research is to determine whether there is an influence of the good governance principles implementation and promotion on receiving of cash waqf fund on the waqf institutions in Indonesia and how the effect of good governance principles implementation and promotion on receiving cash waqf fund on the waqf institutions in Indonesia. The results of the study showed that implementation of the good governance principles have a positive effect but not significant on the receiving cash waqf fund. Promotion have a significant positive effect on receiving of cash waqf fund, then implementation of the good governance principles and promotion simultaneously have a significant positive effect on the receiving cash waqf fund.
\end{abstract}

\begin{abstract}
A B S T R A K
Wakaf tunai adalah wakaf menggunakan uang dengan penerbitan sertifikat wakaf uang oleh lembaga keuangan syariah. Tujuan dari penelitian ini adalah untuk mengetahui apakah terdapat pengaruh dari penerapan prinsip-prinsip good governance dan promosi terhadap penerimaan wakaf tunai di lembaga pengelola wakaf di Indonesia dan seberapa besar pengaruh penerapan prinsip-prinsip good governance dan promosi terhadap penerimaan wakaf tunai di lembaga pengelola wakaf di Indonesia. Hasil penelitian menunjukkan bahwa penerapan prinsip-prinsip good governance berpengaruh positif namun tidak signifikan terhadap penerimaan wakaf tunai. Promosi memiliki pengaruh positif yang signifikan terhadap penerimaan wakaf tunai, kemudian secara simultan penerapan prinsip-prinsip good governance dan promosi memiliki pengaruh positif yang signifikan terhadap penerimaan wakaf tunai.
\end{abstract}

\section{PENDAHULUAN}

Wakaf berasal dari bahasa Arab "Al-Waqf" yang artinya harta yang diwakafkan. Wakaf juga bermakna "Al-Habs" yaitu harta yang ditahan. Wakaf merupakan amal Islami yang berupa tanah atau bangunan. Pengertian wakaf menurut Undang-Undang No. 41 Tahun 2004 adalah:

"Perbuatan hukum wakif untuk memisahkan dan/atau menyerahkan sebagian harta benda miliknya untuk dimanfaatkan selamanya atau untuk jangka waktu tertentu sesuai dengan kepentingannya guna keperluan ibadah dan/atau kesejahteraan umum menurut syariah"

Dalam perkembangannya wakaf tidak hanya berupa aktiva tetap saja namun muncul pula implementasi wakaf menggunakan uang atau lebih dikenal dengan wakaf tunai. Wakaf tunai dihimpun melalui penerbitan sertifikat wakaf tunai oleh lembaga pengelola wakaf. Harta yang diwakafkan berupa uang atau surat berharga dikelola oleh Institusi perbankan atau lembaga keuangan syariah yang kemudian keuntungannya akan disedekahkan. Wakaf yang terkumpul akan diinvestasikan oleh nazhir ke dalam berbagai sektor usaha yang produktif dan halal. 
Catatan Badan Wakaf Indonesia (BWI) tentang aset wakaf uang yang sudah terkumpul di Indonesia per desember 2013 sebesar Rp 145,8 M. Namun, menurut Dirjen Bimbingan Masyarakat Islam Prof Dr Nasaruddin Umar potensi wakaf tunai bisa mencapai $\mathrm{Rp} 20$ triliun pertahun (kemenag.go.id, 2011).

Indonesia memiliki lembaga independen yang bertugas untuk mengembangkan perwakafan, yaitu Badan Wakaf Indonesia (BWI). BWI bersifat bebas yang artinya tidak terpengaruh oleh kekuasaan manapun dalam melaksanakan tugasnya, serta bertanggung jawab kepada masyarakat. BWI merupakan perwujudan amanat dalam Undang-Undang Nomor 41 Tahun 2004 tentang wakaf. Selain bertugas melakukan pengelolaan dan pengembangan harta benda wakaf skala nasional maupun internasional, BWI juga berperan melakukan pembinaan terhadap nazhir agar pengelolaan potensi wakaf dilakukan dengan profesional dan produktif sehingga dapat memberikan manfaat yang terus-menerus bahkan berlipat-lipat.

Namun demikian, dengan potensi wakaf yang cukup besar, tidak semua potensi wakaf dapat terealisasi dengan baik karena lembaga pengelola wakaf tidak mampu mengumpulkan potensi wakaf tersebut. Sangat disayangkan karena betapa besarnya potensi wakaf di Indonesia yang belum terealisasi. Hal ini menunjukan bahwa belum optimalnya lembaga pengelola wakaf dalam menghimpun wakaf tunai di Indonesia.

Adapun masalah yang menjadi penyebab lembaga pengelola wakaf belum optimal menghimpun potensi wakaf adalah masih sedikit wakaf yang dikelola secara profesional dan produktif (bwi.or.id, 2013). Menurut data Kementerian Agama RI Tahun 2010, hampir 95 \% aset wakaf belum dimanfaatkan secara optimal sehingga peran sosial-ekonomi wakaf belum maksimal. Good governance yang masih lemah menyebabkan kepercayaan masyarakat berkurang pada nazhir atau lembaga pengelola wakaf.

Organisasi sektor publik memiliki stakeholder yang lebih luas dibandingkan organisasi swasta. Dengan banyaknya pemangku kepentingan di organisasi sektor publik, maka muncul kewajiban untuk mempertanggungjawabkan kinerjanya kepada berbagai stakeholder (Boland dan Flower, 2000). Fenomena yang muncul terkait organisasi sektor publik adalah semakin menguatnya tuntutan pelaksanaan akuntabilitas publik (Mardiasmo, 2002:20). Tuntutan akuntabilitas publik muncul seiring dengan perlunya dilakukan transparansi dalam rangka pemberian informasi kepada publik untuk memenuhi hak-hak publik Scott (1997).

Hingga saat ini belum ada PSAK yang mengatur tentang wakaf di Indonesia. Sebagai organisasi nirlaba, lembaga pengelola wakaf memiliki kewajiban akuntansi untuk membuat laporan aktivitas, baik itu penerimaan maupun pengeluaran dana sebagaimana diatur dalam PSAK No.45 tentang organisasi nirlaba.

Akuntabilitas sebagai upaya mewujudkan good governance belum membudaya di Indonesia. Akuntabilitas dipandang penting bagi organisasi atau perusahaan. Kelangsungan usaha lembaga pengelola wakaf sebagai organisasi nirlaba ditentukan dari sumbangan yang diberikan oleh pihak-pihak yang percaya pada organisasi tersebut (public trust).

Ketua Dewan Komisioner OJK Muliaman Darmansyah Hadad mengatakan aplikasi GCG di Indonesia masih rendah jika dibandingkan dengan negara lain di kawasan Asia Tenggara. Berdasarkan data dari Indonesian Institute for Corporate Directorship (IICD) pada 2013 Indonesia ada di peringkat kedua terbawah di Asia Tenggara dengan skor 54,55, dan posisi pertama diduduki oleh Thailand dengan skor 75,39 (Yunus, dalam market.bisnis.com, 2014).

Menurut Antonio (2007), terdapat tiga filosofi dasar dalam pengelolaan wakaf yang profesional, yaitu pertama, pola manajemennya harus dalam bingkai proyek yang terintegrasi. Kedua, mengedepankan asas kesejahteraan nazir, yang menyeimbangkan antara kewajiban yang harus dilakukan dan hak yang diterima. Ketiga, asas transparansi dan akuntabilitas".

Akuntabilitas memiliki peranan yang signifikan sebagai parameter profesionalitas pengelolaan wakaf. Budiman (2011) menjelaskan bahwa akuntabilitas yang ada pada lembaga wakaf akan berimplikasi pada semakin kuatnya legitimasi sosial, dimana lembaga itu akan mendapat public trust.Legitimasi dari masyarakat akan menaikkan dukungan masyarakat dalam pengelolaan wakaf".

Pengoptimalan penghimpunan dan pengelolaan wakaf membutuhkan adanya tata kelola yang baik (good governance). Menurut The Indonesian Institute for Corporate Governance (IICG), good corporate governance merupakan serangkaian mekanisme yang mengarahkan dan mengendalikan suatu perusahaan agar operasional perusahaan berjalan sesuai dengan harapan para pemangku kepentingan (stakeholders).

Good governance dipercaya sebagai tolok 
ukur baik atau tidaknya kinerja suatu organisasi. Terdapat lima prinsip dalam good governance yang dikemukakan oleh Komite Nasional Kebijakan Governance (KNKG) yaitu transaparansi, akuntabilitas, responsibilitas, independensi dan keadilan. Upaya penerapan prinsip-prinsip good governance oleh lembaga pengelola wakaf di Indonesia dimaksudkan dapat mendukung penerimaan wakaf tunai.

Tidak hanya tata kelola yang baik yang dibutuhkan oleh lembaga pengelola wakaf di Indonesia untuk mengoptimalkan penghimpunan potensi wakaf tunai di Indonesia, tetapi juga harus melakukan komunikasi dengan stakeholder, orang yang potensial memberi wakaf, dan masyarakat umum. Salah satu cara berkomunikasi yang dapat dilakukan adalah dengan promosi. Lembaga wakaf, yang keberlangsungannya ditentukan oleh dana wakaf dari masyarakat sudah sewajarnya memiliki teknik fundraising salah satunya adalah dalam bentuk promosi atau banyak lembaga pula yang menyebutnya. promosi memegang peranan yang sangat penting, promosi menentukan citra kinerja suatu institusi, serta mempengaruhi masyarakat apakah tertarik menjadi konsumennya atau tidak (Hafidhuddin, 2006). Menurut Bendahara Badan Wakaf Indonesia Prof. Dr. Suparman IA, BWI menggunakan biaya promosi atau bisa juga disebut biaya sosialisasi dengan tujuan memberitahukan, menyadarkan, mengingatkan, mendorong dan memotivasi, menanamkan citra yang kuat dalam benak masyarakat dan memudahkan serta malayani masyarakat untuk menyalurkan wakafnya kepada BWI (bwi.or.id, 2009). Sosialisasi lembaga amil zakat, infaq, sedekah, dan wakaf harus terus menerus dilakukan, karena hal tersebut akan memunculkan kesadaran kolektif masyarakat untuk mau menyalurkan hartanya melalui lembaga tersebut (Hafidhuddin, 2006).

Pada Tabloid Republika edisi Jumat, 19 September 2008 hal. 4, KH Miftah Farid mengungkapkan bahwa $40 \%$ dari total keuangan lembaga amil zakat digunakan sebagai anggaran iklan. Penelitian sebelumnya yang dilakukan oleh Arrafat (2010) menyatakan bahwa biaya promosi mempengaruhi penerimaan zakat, infaq, sedekah, dan wakaf sebesar $44,3 \%$ dan sisanya 55,7\% merupakan pengaruh dari variabel lain yang tidak diteliti.

Berdasarkan uraian diatas, dapat dirumuskan masalah dalam penelitian ini adalah sebagai berikut "Apakah Terdapat Pengaruh Penerapan Prinsip-Prinsip Good Governance dan Promosi Terhadap Penerimaan Wakaf Tunai (pada Lembaga Pengelola Wakaf di Indonesia)"

Adapun tujuan yang ingin dicapai dalam penelitian ini, yaitu :

1) Untuk mengetahui apakah ada pengaruh penerapan prinsip-prinsip good governance terhadap penerimaan wakaf tunai di lembaga pengelola wakaf.

2) Untuk mengetahui apakah ada pengaruh promosi terhadap penerimaan wakaf tunai di lembaga pengelola wakaf.

3) Untuk Mengetahui apakah ada pengaruh penerapan prinsip-prinsip good governance dan promosi terhadap penerimaan wakaf tunai di lembaga pengelola wakaf.

Hasil penelitian ini diharapkan dapat berguna dan bermanfaat bagi penulis dan pihak lain yang bersangkutan. Bagi penulis diharapkan penelitian ini dapat menambah wawasan serta pengetahuan mengenai lembaga pengelola wakaf, khususnya dilihat dari faktor yang mempengaruhi penerimaan wakaf tunai. Bagi lembaga pengelola wakaf, diharapkan penelitian ini menjadi masukan bagi lembaga pengelola wakaf di indonesia untuk dapat meningkatkan penerimaan wakaf tunai. Selanjutnya, bagi peneliti lain diharapkan penelitian ini dapat memberikan tambahan pengetahuan dan pemahaman teoritis serta penerapannya terhadap kondisi nyata di lapangan terutama mengenai masalah penerimaan wakaf tunai.

\section{RERANGKA TEORI}

Beberapa teori yang menjelaskan kerangka penelitian ini antara lain Teori stewardship. Teori tersebut menggambarkan hubungan antara pemilik sumber daya (principal) dan pengelola sumber daya (steward) (Susetyo, 2009). Teori ini memiliki asumsi bahwa pengelola sumber daya dan pemilik sumber daya memiliki keselarasan tujuan dengan tujuan organisasi (Susetyo, 2009). Konsep dasar teori stewardship adalah kepercayaan. Pemilik sumber daya mempercayai pengelola sumber daya dapat melakukan pekerjaannya dengan baik, bertanggung jawab, dan memiliki integritas. Teori stewardship diasumsikan bahwa ada hubungan yang kuat antara kepuasan pemilik sumber daya dan kesuksesan organisasi.

Selanjutnya, menurut World Bank governance yaitu "the way state power is used in managing economic and social resources for development

* Korespondensi penulis: 2 indrisupriyanto@yahoo.com. 
of society". Definisi governance menurut United Nation Development Program (UNDP) adalah "the exercise of political, economic, and administrative authority to manage a nation's affair at all levels". Secara umum good corporate governance dapat diartikan sebagai tata kelola perusahaan yang baik. Terdapat beberapa pemahaman tentang pengertian corporate governance.

Terdapat lima prinsip good governance yang dikeluarkan Komite Nasional Kebijakan Governance (KNKG) yaitu transparansi, akuntabilitas, responsibilitas, independensi dan keadilan.

a. Keterbukaan

Perusahaan harus menyediakan informasi secara tepat waktu, memadai, jelas, akurat dan dapat diperbandingkan serta mudah diakses oleh pemangku kepentingan sesuai dengan haknya. Berdasarkan prinsip keterbukaan, pemangku kepentingan akan dapat melihat informasi yang penting untuk pengambilan keputusan.

b. Akuntabilitas

Prinsip ini mengharuskan perusahaan mempertanggungjawabkan kinerjanya secara transparan dan wajar. Akuntabilitas merupakan prasyarat yang diperlukan untuk mencapai kinerja yang berkesinambungan.

c. Pertanggungjawaban

Perusahaan harus mematuhi peraturan perundang-undangan serta melaksanakan tanggung jawab terhadap masyarakat dan lingkungan sehingga dapat terpelihara kesinambungan usaha dalam jangka panjang dan mendapat pengakuan sebagai good corporate citizen.

d. Independensi

Guna melancarkan pelaksanaan asas good governance, perusahaan harus dikelola secara independen sehingga masingmasing organ perusahaan tidak saling mendominasi dan tidak dapat diintervensi oleh pihak lain. Prinsip ini akan memperlihatkan kepada wakif bahwa setiap pengambilan keputusan di lembaga wakaf dilakukan secara objektif.

e. Keadilan

Pada proses pelaksanaan kegiatannya, perusahaan harus senantiasa memperhatikan kepentingan pemangku kepentingan lainnya berdasarkan asas kewajaran dan kesetaraan. Diberikannya perlakuan yang sama dan kesempatan untuk menyampaikan masukan kepada pemangku kepentingan, besar kemungkinan wakif sebagai salah satu pemangku kepentingan akan kembali mewakafkan hartanya di lembaga wakaf.

Definisi promosi menurut Kotler (2009) adalah "Promotion start for the various activities that the company undertake to communicate its product merits and to persuade target consumers to buy them". Berdasarkan pengertian itu diartikan promosi adalah berbagai macam kegiatan yang dilaksanakan oleh perusahaan untuk mengkomunikasikan keunggulan-keunggulan dari produknya dan untuk membujuk kosumen sasaran untuk membelinya.

Lembaga pengelola wakaf atau yang biasa disebut nazhir adalah adalah pihak yang menerima harta benda wakaf dari Wakif untuk dikelola dan dikembangkan sesuai dengan peruntukannya. Nazhir dapat berupa perorangan, organisasi maupun badan hukum.

Wakaf adalah berasal dari bahasa Arab "Al-Waqf" yang artinya harta yang diwakafkan. Wakaf juga bermakna "Al-Habs" yaitu harta yang ditahan. Wakaf merupakan amal Islami yang berupa tanah atau bangunan. Menurut UndangUndang No. 41 Tahun 2004 tentang Wakaf,

"Wakaf adalah perbuatan hukum wakif untuk memisahkan dan/atau menyerahkan sebagian harta benda miliknya untuk dimanfaatkan selamanya atau untuk jangka waktu tertentu sesuai dengan kepentingannya guna keperluan ibadah dan/atau kesejahteraan umum menurut syariah" (UU No. 41/2004, 1:1).

Wakaf tunai merupakan hal baru di Indonesia yang merupakan produk dari Undang Undang No.41 Tahun 2004. Wakaf tunai menurut UU No.41 tahun 2004 pasal 28 sampai pasal 31 yaitu wakaf benda bergerak berupa uang yang diterbitkan dalam bentuk sertifikat wakaf uang oleh lembaga keuangan syariah sebagai bukti penyerahan harta benda wakaf.

Definisi wakaf tunai menurut Mohsin (2007) yaitu,

"Cash-Waqf can be defined as the confinement of an amount of money/cash from the founder and dedicated of its usufruct, according to founder's condition(s), in perpetuity to the welfare of the society".

\section{METODE PENELITIAN}

Metode penelitian yang digunakan dalam penelitian ini adalah metode deskriptif dengan menggunakan pendekatan survei. Menurut 
Sugiono (2011) Metode deskriptif merupakan suatu metode yang digunakan untuk mendeskripsikan atau memberi gambaran terhadap objek yang diteliti melalui data atau sampel yang telah dikumpulkan sebagaimana adanya tanpa melakukan analisis dan membuat kesimpulan yang berlaku untuk umum. Dengan kata lain penelitian deskriptif analitis yaitu mengambil masalah atau memusatkan perhatian kepada masalah-masalah yang diteliti baik itu sekelompok manusia, suatu objek, suatu kondisi, suatu pemikiran, ataupun suatu kelas peristiwa pada masa sekarang dengan tujuan mendapatkan deskripsi sistematis yang kemudian diolah dan dianalisis untuk diambil kesimpulannya.

Menurut Indriantoro (1999:26) pendekatan survei adalah teknik pengumpulan dan analisis data berupa opini dari subyek yang diteliti (responden) melalui metode tanya jawab. Metode survei dapat membedah dan mengenal masalahmasalah serta mendapatkan pembenaran terhadap keadaan maupun praktek-praktek yang sedang berlangsung (Nazir, 1988:65).

Pemilihan sampel dalam penelitian ini menggunakan teknik purposive sampling. Purposive sampling merupakan teknik penentuan sampel penelitian dengan pertimbangan tertentu. Pertimbangan penulis dalam memilih sampel adalah ;

1. Lembaga pengelola wakaf yang tidak termasuk lembaga keuangan mikro

2. Lembaga pengelola wakaf yang bersedia untuk berpartisipasi dalam penelitian ini.

Berdasarkan kriteria-kriteria yang telah ditetapkan sebelumnya, penelitian ini dilakukan di 6 lembaga pengelola wakaf yang memenuhi kriteria tersebut, yaitu: Dompet Dhuafa, Sinergy Foundation, Wakaf Daarut Tauhiid, Badan Wakaf Indonesia, Rumah Wakaf Indonesia, Posko Keadilan Peduli Umat.

Dalam penelitian ini, penulis menggunakan dua jenis data, yaitu data primer dan data sekunder. Data primer yaitu data yang diperoleh dari hasil kuesioner yang disebarkan kepada responden. Data sekunder yaitu data yang telah ada dan tersusun secara sistematis. Data sekunder dapat berupa hasil penelitian atau rangkuman dari dokumen-dokumen serta literatur lain seperti buku, majalah, surat kabar, makalah dan situs web.

Metode analisis yang digunakan adalah metode statistik dengan menggunakan analisis korelasi dan analisis regresi linear berganda. Tahap-tahap yang dilakukan adalah regresi linear berganda, analisis korelasi, uji $t$ dan analisis koefisien determinasi.

\section{ANALISIS DAN PEMBAHASAN}

Analisis penelitian dengan menggunakan regresi berganda dapat dicari dengan menggunakan persamaan sebagai berikut:

$$
\mathrm{Y}=\mathrm{a}+\mathrm{b} 1 \mathrm{X} 1+\mathrm{b} 2 \mathrm{X} 2+\mathrm{e}
$$

Tabel 1. Hasil Analisis Regresi Berganda

\begin{tabular}{|c|c|c|c|}
\hline & Koefisien & $\mathrm{t}$ & Sig \\
\hline C & 0,067 & 0,120 & 0,906 \\
\hline GCG & 0,332 & 1,157 & 0,265 \\
\hline Promosi & 0,782 & 2,713 & 0,016 \\
\hline $\mathrm{R}$ & 0,853 & & \\
\hline $\mathrm{R}^{2}$ & 0,728 & & \\
\hline $\mathrm{F}$ & 20,028 & & 0,000 \\
\hline
\end{tabular}

Sumber : data diolah

Berdasarkan hasil perhitungan pada tabel diatas, diperoleh bentuk persamaan regresi linear ganda sebagai berikut :

$$
\mathrm{Y}=0,067+0,332 \mathrm{X} 1+0,782 \mathrm{X} 2+\mathrm{e}
$$

Persamaan regresi linear ganda diatas menunjukkan nilai konstanta sebesar 0,135. Hal ini bermakna bahwa ketika variabel penerapan prinsip - prinsip good governance (X1) dan promosi (X2) bernilai nol atau penerimaan wakaf tunai $(\mathrm{Y})$ tidak dipengaruhi oleh penerapan prinsip - prinsip good governance dan promosi, maka besarnya penerimaan wakaf tunai 0,067 .

Koefisien regresi untuk variabel bebas X1 bernilai positif sebesar 0,332. Ini berarti menunjukan adanya hubungan searah penerapan prinsip - prinsip good governance terhadap penerimaan wakaf tunai. Nilai koefisien regresi sebesar 0,332, artinya setiap peningkatan satu satuan penerapan prinsip - prinsip good governance akan meningkatkan penerimaan wakaf sebesar 0,332 dengan asumsi variabel independen lainnya tetap.

Koefisien regresi untuk variabel bebas X2 bernilai positif sebesar 0,782. Ini berarti menunjukan adanya hubungan searah promosi terhadap penerimaan wakaf tunai. Nilai koefisien regresi sebesar 0,782, artinya setiap peningkatan satu satuan promosi akan meningkatkan penerimaan wakaf tunai sebesar 0,782 dengan asumsi variabel independen lainnya tetap.

Nilai dari koefisien regresi promosi lebih besar dibandingkan penerapan prinsip - prinsip good governance, berarti kenaikan wakaf tunai lebih tinggi jika promosi naik satu satuan. Hal ini menunjukan bahwa promosi lebih mempengaruhi penerimaan wakaf tunai pada lembaga pengelola wakaf. Promosi lebih mempengaruhi penerimaan 
wakaf tunai disebabkan oleh wakif yang tidak selalu menilai akuntabilitas, transparansi, dan unsur-unsur good governance lain, wakif lebih tertarik menyalurkan hartanya pada lembaga wakaf yang gencar mempromosikan produknya.

Secara statistik dukungan atas hipotesis penelitian setidaknya dapat diukur dari nilai koefisien determinasi, uji $F$ dan nilai uji $t$. Perhitungan statistik disebut signifikan apabila nilai uji statistiknya berada dalam daerah kritis (Ho ditolak), sebaliknya tidak signifikan bila nilainya berada dalam daerah dimana Ho diterima (Ghozali, 2001).

Berdasarkan hasil analisis, diperoleh nilai koefisien korelasi (R) sebesar 0,853. Dapat disimpulkan bahwa hubungan penerapan prinsipprinsip good governance dan promosi lembaga pengelola wakaf terhadap penerimaan wakaf termasuk pada kategori sangat kuat.

Analisis juga menunjukkan nilai koefisien determinasi $\left(R^{2}\right)$ sebesar 0,728. Nilai tersebut bermakna bahwa sebesar 0,728 perubahanperubahan yang terjadi pada penerimaan wakaf tunai disebabkan oleh penerapan prinsip-prinsip good governance dan promosi lembaga pengelola wakaf. Sisanya 0,272 atau $27,2 \%$ menunjukkan bahwa perubahan yang terjadi pada penerimaan wakaf tunai disebabkan oleh faktor lain yang tidak diteliti dalam model ini.

Selanjutnya, Tabel 1 menunjukkan bahwa F hitung adalah sebesar 20.029 dan nilai signifikansi sebesar 0,000. Dengan menggunakan batas signifikansi 0,05 , nilai signifikansi tersebut berada di bawah 5\% yang menunjukkan H0 ditolak dan HA diterima. Hal ini berarti penerapan prinsipprinsip good governance (X1) dan promosi (X2) berpengaruh secara simultan terhadap penerimaan wakaf tunai $(\mathrm{Y})$.

Penelitian menggunakan batas $t_{\text {tabel }}$ sebesar 2.1199. Variabel penerapan prinsip - prinsip good governance $(\mathrm{X} 1)$, menunjukkan bahwa nilai $\mathrm{t}_{\text {hitung }}$ adalah sebesar 1.157 dan nilai signifikansi sebesar 0,265 dan nilai beta 0,266 . Nilai beta lebih besar dari nol, dan batas signifikan 5\% yang artinya H0 ditolak. Artinya penerapan prinsip - prinsip good governance (X1) secara parsial berpengaruh positif namun tidak signifikan terhadap penerimaan wakaf tunai $(Y)$.

Variabel promosi (X2) menunjukkan bahwa nilai thitung adalah sebesar 2.713 dan nilai signifikansi sebesar 0,016. Dengan menggunakan batas signifikansi 0,05, nilai signifikansi berada di bawah $5 \%$ dan $t_{\text {hitung }}$ lebih besar dari $t_{\text {tabel }}$ yang menunjukkan tersebut $\mathrm{HO}$ ditolak dan HA diterima. Artinya promosi (X2) secara parsial berpengaruh secara signifikan terhadap penerimaan wakaf tunai $(\mathrm{Y})$. Nilai thitung yang positif berarti semakin tinggi promosi lembaga pengelola wakaf, semakin tinggi pula penerimaan wakaf tunai.

Berdasarkan hasil analisis dengan uji statistik, didapatkan hasil bahwa terdapat pengaruh yang signifikan atas penerapan prinsipprinsip good governance dan promosi secara simultan terhadap penerimaan wakaf tunai di lembaga pengelola wakaf. Hasil tersebut didasarkan pada uji $\mathrm{F}$ yang telah dilakukan sebelumnya, yang melihat pengaruh secara simultan kedua variabel independen terhadap variabel dependen. Berdasarkan uji $\mathrm{F}$ yang telah dilakukan, dengan tingkat kepercayaan sebesar 95\% didapatkan F hitung sebesar 20,028 dan nilai signifikansi sebesar 0,000 maka H0 ditolak. Sehingga, dapat disimpulkan bahwa penerapan prinsip-prinsip good governance dan promosi berpengaruh positif secara signifikan terhadap penerimaan wakaf tunai di lembaga pengelola wakaf.

Berdasarkan hasil analisis koefisien korelasi berganda, didapatkan angka $\mathrm{R}$ sebesar 0,853 yang mencerminkan bahwa korelasi variabel independen dan variabel dependen tersebut bersifat erat. Nilai koefisien determinasi $\left(R^{2}\right)$ yang didapatkan, yaitu sebesar $72,8 \%$, menunjukkan persentasi partisipasi dari penerapan prinsipprinsip good governance dan promosi yang cukup tinggi dalam menjelaskan pengaruhnya terhadap penerimaan wakaf tunai di lembaga pengelola wakaf.

Hasil penelitian ini mendukung teori yang ada. Secara teori penerapan tata kelola yang baik termasuk memiliki program promosi dalam suatu lembaga pengelola wakaf akan berpengaruh dalam penerimaan wakaf tunai. Wakaf tunai merupakan hal yang baru di Indonesia, tidak semua golongan masyarakat memahami apa itu wakaf tunai karena yang dipahami oleh semua orang wakaf itu berbentuk tanah atau bangunan saja. Karena itu promosi yang baik akan memberikan edukasi bagi masyarakat yang sebelumnya tidak mengetahui apa itu wakaf tunai, seperti yang dituliskan oleh penelitian sebelumnya oleh Hafidhuddin (2006) yang menyatakan bahwa sosialisasi lembaga amil zakat, infaq, sedekah, dan wakaf harus terus menerus dilakukan, karena hal tersebut akan memunculkan kesadaran kolektif masyarakat untuk mau menyalurkan hartanya melalui lembaga tersebut. 
Responden penelitian ini adalah lembaga pengelola wakaf baik yang telah fokus mengelola wakaf maupun yang masih tergabung dalam lembaga ZISWAF. Beberapa lembaga seperti Dompet Dhuafa, Rumah Zakat, dan Daarut Tauhiid telah melakukan pemisahan untuk wakaf dari entitas pengelola zakat, infaq dan sedekahnya, sementara itu beberapa lembaga filantropi masih menggabungkan pengelolaan wakaf di dalam entitas yang mengelola zakat, infaq dan sedekah.

Menurut Direktur Eksekutif BWI Drs. H Achmad Djunaedi, MBA, wakif lebih tertarik menyalurkan harta wakafnya kepada lembaga pengelola wakaf atau nazhir wakaf tunai yang memiliki program yang menarik bukan karena melihat efisiensi atau laporan wakafnya. Program menarik yang dimaksud adalah program atau produk yang belum pernah diketahui sebelumnya oleh wakif serta dianggap manfaatnya terus menerus dan berlipat seperti wakaf untuk pembangunan pesantren, wakaf untuk tempat usaha, wakaf untuk lahan produktif, dan bentuk penyaluran wakaf tunai lainnya.

Meskipun belum ada pedoman akuntansi yang khusus mengatur wakaf tunai di indonesia, namun laporan keuangan yang diterbitkan oleh sebagian besar nazhir sudah cukup jelas mengenai keluar masuknya dana wakaf. Perbandingan kinerja nazhir wakaf tunai melalui laporan keuangan dirasa tidak dapat dijadikan aucan utama, selain karena perlakuan akuntansi yang belum sama antar nazhir wakaf tunai atau lembaga pengelola wakaf beberapa nazhir wakaf tunai juga masih menggabungkan beberapa kegiatan dalam pengelolan wakaf bersamaan dengan kegiatan pengelolaan zakat, infaq dan sedekah.

Berdasarkan hasil analisis data dengan uji statistik, didapatkan hasil bahwa terdapat pengaruh positif namun tidak signifikan atas penerapan prinsip-prinsip good governanceterhadap penerimaan wakaf tunai. Hasil tersebut didasarkan pada uji $\mathrm{t}$ yang telah dilakukan sebelumnya. Berdasarkan uji $\mathrm{t}$ yang telah dilakukan, dengan tingkat kepercayaan sebesar 95\% didapatkan $t$ hitung sebesar 1,157 dan nilai signifikansi sebesar 0,265 serta nilai beta sebesar 0,266 . Nilai beta lebih besar dari 0 dengan batas signifikansi 5\% maka $\mathrm{H} 0$ ditolak.Sehingga, dapat disimpulkan bahwa penerapan prinsip-prinsip good governance berpengaruh positif namun tidak signifikan terhadap penerimaan wakaf tunai.

Kelangsungan usaha lembaga pengelola wakaf sebagai organisasi nirlaba ditentukan dari sumbangan yang diberikan oleh pihak-pihak yang percaya pada organisasi tersebut (public trust). Hasil penelitian ini sesuai dengan teori stewardship yang didasari oleh konsep kepercayaan. Teori stewardship yang menyebutkan bahwa pemilik sumber daya mempercayai pengelola sumber daya dapat melakukan pekerjaannya dengan baik. Teori ini berlaku bagi lembaga filantropi karena teori ini memiliki asumsi bahwa pengelola sumber daya dan pemilik sumber daya memiliki keselarasan tujuan dengan tujuan organisasi. Asas kepercayaan ini menyebabkan wakif sebagai pemilik sumber daya tidak semuanya mengamati laporan keuangan sebagai cerminan penerapan good governance yang baik, namun wakif lebih memilih untuk melihat publikasi penyaluran harta wakaf tersebut sehingga wakif merasa yakin bahwa harta yang diwakafkan tersebut disalurkan sesuai dengan program nazhir dan keinginan wakif.

Berdasarkan hasil analisis data dengan uji statistik, didapatkan hasil bahwa terdapat pengaruh positif yang signifikan atas promosi terhadap penerimaan wakaf tunai. Hasil tersebut didasarkan pada uji $\mathrm{t}$ yang telah dilakukan sebelumnya. Berdasarkan uji $t$ yang telah dilakukan, dengan tingkat kepercayaan sebesar 95\% didapatkan $t$ hitung sebesar 2,713 dan nilai signifikansi sebesar 0,016 serta nilai beta sebesar 0,623 . Nilai Beta lebih besar dari nol, kemudian nilai $t$ hitung tersebut lebih besar dari $t$ tabel positif dan nilai Sig. pun lebih kecil dari 0,05, maka H0 ditolak sehingga, dapat disimpulkan bahwa promosi berpengaruh secara positif signifikan terhadap penerimaan wakaf tunai.

Hasil penelitian ini mendukung hasil penelitian lain dari Arrafat (2010) yang menyatakan bahwa biaya promosi mempengaruhi penerimaan zakat, infaq, sedekah, dan wakaf sebesar $44,3 \%$. Jannah (2015) dalam penelitiannya menyebutkan bauran promosi memiliki pengaruh terhadap peningkatan penghimpunan dana wakaf di Pusat Pengembangan Wakaf Daarut Tauhiid, dan pengaruhnya sangat kuat. Sosialisasi lembaga amil zakat, infaq, sedekah, dan wakaf harus terus menerus dilakukan, karena hal tersebut akan memunculkan kesadaran kolektif masyarakat untuk mau menyalurkan hartanya melalui lembaga tersebut (Hafidhuddin, 2006). Wakaf tunai merupakan sesuatu yang baru di Indonesia oleh sebab itu promosi dapat mempengaruhi penerimaan wakaf tunai secara signifikan. Promosi dapat memberikan pemahaman kepada masyarakat mengenai wakaf tunai, selain itu dengan promosi yang baik masyarakat akan tertarik untuk menyalurkan hartanya. 


\section{SIMPULAN}

Berdasarkan hasil penelitian dan pembahasan, dapat ditarik kesimpulan sebagai berikut:

1) Hasil penelitian menunjukan bahwa terdapat pengaruh positif namun tidak signifikan dari penerapan prinsip-prinsip good governance terhadap penerimaan wakaf tunai yang artinya semakin baik penerapan prinsip-prinsip good governance maka akan semakin tinggi pula penerimaan wakaf tunai pada lembaga pengelola wakaf di Indonesia.

2) Hasil penelitian menunjukan bahwa adanya pengaruh positif dari promosi terhadap penerimaan wakaf tunai yang artinya semakin tinggi tingkat promosi maka semakin tinggi pula penerimaan wakaf tunai pada lembaga pengelola wakaf di Indonesia.

3) Penerapan prinsip-prinsip good governance dan promosi secara simultan memiliki pengaruh yang positif terhadap penerimaan wakaf tunai pada lembaga pengelola wakaf di Indonesia.

Berdasarkan hasil penelitiandan pembahasan yang telah dijelaskan, pada bagian ini penulis bermaksud menyampaikan saran-saran yang diharapkan dapat berguna bagi pihakpihakyang berkepentingan. Saran tersebut adalah sebagai berikut :

1) Saran untuk lembaga pengelola wakaf tunai :

a. Penerapan prinsip-prinsip good governance pada lembaga pengelola wakaf masih harus ditingkatkan. Beberapa poin dalam penerapan prinsipprinsip good governance yang masih perlu ditingkatkan berdasarkan jawaban responden adalah kejelasan informasi dalam laporan keuangan, publikasi laporan keuangan, pengungkapan secara penuh (full disclosure), komparabilitas agar laporan keuangan dapat diperbandingkan dengan lembaga wakaf lain, serta sistem reward and punishment yang merata.

b. Promosi merupakan faktor penting dalam mensosialisasikan wakaf tunai dalam penghimpunan dan pendayagunaan dana wakaf. Lembaga pengelola wakaf diharapkan dapat mempromosikan secara masif lagi baik program penghimpunan wakaf tunai maupun program dalam penyaluran wakaf. Berdasarkan jawaban responden, pengenalan produk dan pemasaran langsung kepada calon nasabah masih perlu ditingkatkan lagi karena hasil survei menunjukan masih ada lembaga yang belum menerapkannya.

Beberapa saran untuk peneliti selanjutnya antara lain:

a. Agar hasil penelitian bisa lebih maksimal, jumlah sampel diperbanyak jika memungkinkan.

b. Meneliti hal-hal yang masuk dalam keterbatasan penelitian ini.

c. Dapat menambahkan variabel independen lain yang dapat menjadi faktor yang mempengaruhi penerimaan wakaf tunai pada lempaga pengelola wakaf. Karena nazhir wakaf tunai kedepannya diharuskan melakukan penerimaan wakaf melalui LKS-PWU, maka LKS-PWU dapat menjadi variabel penelitian dalam mengukur penerimaan wakaf tunai.

d. Saran untuk pemerintah, pemerintah hendaknya melakukan pemantauan agar tidak terjadi pengabaian regulasi di lembaga pengelola wakaf.

Saran untuk masyarakat, masyarakat hendaknya lebih memahami mekanisme penerimaan maupun penyaluran wakaf tunai dan mulailah berwakaf, karena wakaf tunai memungkinkan masyarakat untuk berwakaf dengan nominal yang relatif kecil.

\section{DAFTAR PUSTAKA}

Abdel, Mohsin Magda Ismail. 2009. Cash Waqf A New Financial Product, Malaysia. Pearson.

Al Arif, M Nur Rianto. 2010. "Pemberdayaan Masyarakat Berbasis Wakaf Uang". Jurnal Asy-Syir'ah. Vol. 44, No. II, 813 - 828

2012. “Efek Multiplier Wakaf Uang dan Pengaruhnya terhadap Program Pengentasan Kemiskinan". Jurnal AsySyirah. Vol. 46, No. I, 297 - 314

Amin, Widjaja Tunggal. 2009. Manajemen Strategik untuk Memenangkan Kompetisi, Jakarta. Harvindo. 
Antonio, M.Syafi'i. 2007. Pengelolaan Wakaf secara Produktif. Jakarta. Mumtaz Publishing.

Arief, Achmad Budiman. 2011. "Akuntabilitas lembaga pengelolaan wakaf" Walisongo, Volume 19, Nomor 1.

Badan Wakaf Indonesia. 2012. Laporan Wakaf Uang di BWI Tahun 2007-2011.

\section{Memproduktikan Aset Wakaf Nasional.} Situs internet BWI. http://bwi.or.id/index.php/in/pu blikasi/artikel/1199 Diakses Maret 2015)

Buchari, Alma. 2002. Manajemen Pemasaran dan Pemasaran Jasa. Bandung, CV Alvabeta:

Carter, Usry. 2006. Akuntansi Biaya. Jakarta. Salemba Empat

Forum for Corporate Governance in Indonesia (FCGI). 2001. Corporate Governance : Tata Kelola Perusahaan. Edisi ketiga. Jakarta. FCGI

2003. Indonesia Company Law. Available online at www.fcgi.org.id (Diakses Maret 2015)

Fowler, Alan and Tony Boland. 2000. A System of Performance Management in Public Sector Organization. International Journal of Public Sector Management. Vol 13 Issue 15.

Ghozali, Imam. 2001. Aplikasi Analisis Multivariate Dengan Program SPSS. Semarang.

Badan Penerbit Universitas Diponegoro

Gibson, James I. 1997. Organisasi Perilaku Struktur Proses. Edisi Ke delapan. Jakarta. Bina Rupa Aksara.

Hafidhuddin, Didin. 2006. "Analisis efektivitas promosi lembaga amil zakat dalam penghimpunan zakat bagi peningkatan kesejahteraan keluarga dhuafa (Studi kasus lembaga amil zakat Dompet Dhuafa Republika)". Jurnal Media Gizi E Keluarga, 30(1): 100-109.

Hidayat. 1986. Teori Efektifitas Dalam Kinerja
Karyawan. Yogyakarta. Gajah Mada

University Press.

Ihsan, Hidayatul \& Muhammad Akhyar Adnan. 2009. Waqf Accounting and the construction of accountability. Malaysia. Waqf Laws and Management Conference, International Islamic University.

Ija. 2013. Badan Wakaf Indonesia Jabar resmi dikukuhkan.

http://www.beritawakaf.com/2013/02/ba dan-wakaf indonesia-jabar resmi.html (Diakses Maret 2015)

Ikatan Akuntan Indonesia. Pelaporan Keuangan Organisasi Nirlaba PSAK No. 45Jakarta:

Ikatan Akuntan Indonesia.

Indonesian Institute for Corporate Governance (IICG). 2009. Corporate Governance Perception Index. Available on-line at http://www.iicg.org, (Diakses Maret 2015).

Indriantoro dan Supomo. 1999. Metodologi Penelitian Bisnis - Untuk Akuntansi dan Manajemen. Yogyakarta. BPFE-Yogyakarta.

Jannah, Ghina Roudhotul, dkk. 2015. “Pengaruh bauran promosi yang islami terhadap peningkatan penghimpunan dana wakaf di Pusat Pengembangan Wakaf Daarut Tauhiid". Bandung. Prosiding Penelitian SPeSIA.

Kementrian Agama Republik Indonesia. 2011. Potensi Wakaf Tunai Mencapai Rp 20 Triliun. http:// kemenag.go.id/index.php?a=berita $\&$ id $=85129$, (Diakses April 2015)

Komite Nasional Kebijakan Governance. 2006. Pedoman Umum Good Corporate Governance Indonesia. Jakarta. KNKG.

2012. Prinsip-prinsip good governance. Available on-line at http://knkg.indonesia.com (Diakses Maret 2015)

Kotler, Philip dan Armstrong, Garry, 2008. Prinsipprinsip Pemasaran, Jilid 1, Jakarta. Erlangga. 
Kotller, Philip and Keller Kevin Lane. 2009. Marketing Management, 13th ed. New Jersey. Prentice Hall,Inc.

Lajnah Pentashih Mushaf Al-Qur'an. 2009. AlQur'an dan Terjemahnya. Bandung. CV Penerbit Diponegoro.

Lubis, Hari. S.B. dan Martani Husaini. 1987. Teori Organisasi (Suatu Pendekatan Makro). Jakarta. Pusat Antar Universitas Ilmu-ilmu Sosial Universitas Indonesia.

Mardiasmo. 2002. Akuntansi Sektor Publik. Edisi Pertama. Yogyakarta. PBFE

Nazir, M. 1988. Metode Penelitian. Jakarta. Ghalia Indonesia.

Novatiani, R. Ait dan Jeanny Fatimmah. 2013. Pengaruh penerapan good corporate governance terhadap keandalan laporan keuangan (survei pada tiga perusahaan BUMN di bidang jasa di Bandung). Bandung. Fakultas Ekonomi Universitas Kristen Maranatha

Osman, Ahmad Zamri. 2010. Accountability of waqf management: insight frompraxis of nongovernmental organisation (NGO). London. Royal Holloway University.

Peraturan Pemerintah Republik Indonesia No.42 Tahun 2006 tentang Pelaksanaan Undang-Undang No.41 Tahun 2004 tentang Wakaf.

Republika 2008, Tabloid Republika / Jumat, 19 September 2008 / Hal 4. Bandung Republika

Ruslan, Heri. 2012. Potensi wakaf uang sungguh luar biasa. Situs internet Republika Online. http://www.republika.co.id/berita/dunia islam/islamnusantara/12/07/22/m7jb3wpotensi-wakaf-uang-sungguh-luar biasa.htm.(Diakses April 2015).

Scott, William R. (1997). Financial Accounting Theory, International Edition, New Jersey : Prentice-Hall, Inc.

Sekaran, Uma. 2006. Metodologi Penelitian untuk
Bisnis. Edisi 4, Buku 1. Jakarta. Salemba Empat.

2006. Metodologi Penelitian untuk Bisnis. Edisi 4, Buku 2. Jakarta. Salemba Empat.

Stanton, William, J. 1996. Prinsip Pemasaran, Edisi ketujuh, jilid 2, cetakan keempat. Gelora Aksara Pratama.

Sudiaman, Maman. 2014. BWI : Potensi wakaf indonesia capai 120 triliun. http://www.republika.co.id/berita/duniai slam/wakaf/14/05/23/n615ie-bwi potensi wakaf-indonesia-capai-120triliun.htm (Diakses Maret 2015)

Sugiyono. 2011. Statistika untuk Penelitian. Bandung. Alfabeta.

Susetyo, Budi. 2009. "Menuju Teori Stewardship Manajemen". Jurnal Permana. Vol. 1 No.1.

Undang-Undang Republik Indonesia No.41 Tahun 2004 tentang Wakaf.

Yasser Arrafat. 2010. Pengaruh Biaya Promosi Terhadap Penerimaan Zakat, Infaq, Sedekah, dan Wakaf. Skripsi sarjana yang tidak dipublikasi. Universitas Padjadjaran

Yunus, Yusran. 2014. GCG Asia Tenggara: Menyedihkan, peringkat RI nomor dua dari bawah. (Diakses Maret 2015). 